\title{
Description of BHK-21Persistent Infected Cell Inoculated with Infectious Bovine Rhinotracheitis Virus
}

\author{
Dewi Noor Hidayati \\ Departement of Product Development \\ Pusat Veteriner Farma \\ Surabaya, Indonesia \\ dewinoorhid@gmail.com \\ Soedarmanto Indarjulianto \\ Department of Internal Medicine \\ Faculty of Veterinary Medicine, \\ Universitas Gadjah Mada \\ Yogyakarta, Indonesia \\ indarjulianto@yahoo.com
}

\author{
Isnoer Aini \\ Departement of Vaccines Production \\ Pusat Veteriner Farma \\ Surabaya, Indonesia \\ isnoeraini@gmail.com
}

\author{
Dyah Pancawidyana \\ Departement of Vaccines Production \\ Pusat Veteriner Farma \\ Surabaya, Indonesia \\ diahpanca3101@gmail.com
}

\begin{abstract}
Infectious Bovine Rhinotracheitis (IBR) disease caused by Bovine Herpesvirus-1 (BHV-1), this diseases include in strategic diseases. Based on the genotype, this virus divided into several subtypes, including subtype 1.1; subtype 1.2a and subtype 1.2b. The previous genotypic study revealed that based on the insertion-deletion of UL36 gene, samples divided into subtype 1.1 and subtype 1.2. This study aim was comparing phenotypic images of isolates from Lampung and Bukittinggi in MDBK and BHK-21 cells. Samples of swab nasal and tracheal organ obtained from Balai Veteriner Lampung and Balai Veteriner Bukittinggi. The samples were cultured on MDBK and BHK-21 monolayer cell of 2 days old obtained from Pusvetma. The Cytopathogenic Effects (CPE) in MDBK and BHK-21 observed on day 2. In the MDBK cell, the CPE found as the grape-like cluster and apoptosis. The CPE of BHK-21 cell line showed syncytium and indicated persistent infection. At day four on BHK-21 cell, it observed the particular infected cell that showed differences in cell shape between samples that have proximity to subtype 1.1 and subtype 1.2. The infected cell of subtype 1.1 group, appear as elongated shape and linear pattern near the center area. Inversely, the samples grouped as subtype $\mathbf{1 . 2}$ appear as rounded cell and circular pattern of the center area.
\end{abstract}

Keywords-IBR, subtype 1.1, subtype 1.2b, UL36 gene, MDBK, BHK-21

\section{INTRODUCTION}

Infectious Bovine Rhinotracheitis (IBR) caused by Bovine Herpesvirus-1 (BHV-1) and represented domestic and free-range cattle disease [1]. This disease is one of the strategic infectious animal diseases according to the Decree of the Minister of Agriculture No. 4026/Kpts/OT.140/04/2013. This virus has a significant impact on the livestock sector because it causes acute respiratory problems, decreased milk production, weight loss, and reproductive disorders such as abortion. The BHV-1 infection-induced immune suppression [2] that could subsequently initiate the entrance of bovine respiratory disease complex (BRDC) called "shipping fever". The BRDC inflicted massive loss in the cattle industry; for example, it inflicted 3 billion annual loss in USA [3]. The Bovine Herpesvirus-1 strain classified into three subtypes, which are BHV-1.1, BHV-1.2a dan BHV$1.2 \mathrm{~b}$ [4] and BHV 1.3 that are subsequently classified into BHV-5 [5]. Bovine Herpesvirus subtype 1.1 shows higher virulence compared to subtype 1.2b [6]. Subtype 1.1 is considered the most pathogenic strain and associated with abortion. Inversely subtype $1.2 \mathrm{~b}$ is not associated with abortion [7]. Indonesian government is currently attempting to produce IBR inactivated vaccines using local isolates [8]. Low virulence and high immunogenic isolates are suitable for vaccine candidates [9]. Subtype-1.2b is considered to have lower pathogenicity compared to 1.1-subtype [10]. Diversity among $1.2 \mathrm{~b}$ strains has determined by the presence of insertion-deletion (indel) on UL36 genes [11] UL36 gene has high differentiation compared with other genes [12]. Insertion-deletion and amino acid substitution at UL36 occurred at 450 aa near $C$ terminus [11]. The study of genetic variability in herpesvirus is interesting and always related to cellular phenotypic description [13]. According to the previous study, Indonesian IBR isolates collected from Lampung and Bukittinggi were belong to into subtype 1.1 and subtype 1.2 based on UL36 gene [14]. This research aim was to describe the phenotypic characterization of the Indonesian samples based on the insertion-deletion of UL36 gene characterization.that could subsequently initiate the entrance of bovine respiratory disease complex (BRDC) called "shipping fever". materials and methods

\section{MATERIALS AND METHODS}

\section{A. Ethical approval}

This research approved by letter of approval for material transfer No. 05010/PD.650/F5.H/06/2015 from The Animal Disease Investigation Centre Lampung and letter No. 22022/PK.310/F4/02/2016 from The Animal Disease Investigation Centre Bukittinggi. The samples have been characterized based on UL 36 genes and deposited on the DDBJ (DNA Data Bank of Japan). 


\section{B. Cell preparation}

BHK-21 cells were cultured as follows : cells was transferred using a sterile glass pipette into $9 \mathrm{ml}$ DMEM containing $10 \%$ FBS, glutamine, 100 IU penicillin and 100 $\mu \mathrm{g} / \mathrm{mL}$ streptomycin. The cell mixture was centrifuged at $1000 \mathrm{rpm}$ for 10 minutes to get pellets. After centrifugation, the supernatant was taken, and the cell pellet was suspended with $10 \mathrm{ml}$ DMEM containing growth medium. The suspension was then transferred to the cell culture microtiter plate, then incubated $37^{\circ} \mathrm{C}$, under $5 \% \mathrm{CO} 2$. Cells were observed every day until they appeared confluent.

\section{Viral inoculation}

The viral suspension $(1 \mathrm{ml})$ from nasal swabs, organs, and PBL was inoculated into monolayer BHK-21 cells aged two days, which had been confluent in a $15 \mathrm{ml}$ cell culture flask. The virus was absorbed for 1 hour and then $9 \mathrm{ml}$ of maintenance media (DMEM containing kanamycin, streptomycin, penicillin, Hepes, $\mathrm{NaHCO} 3$, and L glutamine) and $2 \%$ Fetal Bovine Serum ( FBS free BVD, Sigma Aldrich). The BHK-21 cells are observed every day to find the presence of cytopathogenic effect (CPE) for 6-7 observation days.

\section{Viral characterization}

The samples were characterized based on UL 36 genes and deposited on the DDBJ (DNA Data Bank of Japan) [14] as represented in Table 1 .

TABLE I. THE CHARACTERIZATION OF VIRAL SAMPLES BASED ON THE “GAP” OF UL36 GEN [14]

\begin{tabular}{|c|c|c|c|c|}
\hline $\mathbf{G}$ & Sequence & Variation in $U I$ & & \\
\hline o & & nt allele & a a allele & $R S$ \\
\hline p & & & & \\
\hline & AJ004801 & GACGCGTACCCGCCGGCCCCCGCGCAC & DAYPPAPAH & $2+$ \\
\hline & KU198480 & GACGCGTACCCGCCGGCCCCCGCGCAC & DAYPPAPAH & $2+$ \\
\hline 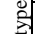 & JX8982201 & GACGCGTACCCGCCGGCCCCCGCGCAC & DAYPPAPAH & $2+$ \\
\hline ह & KY2159441 & GACGCGTACCCGCCGGCCCCCGCGCAC & DAYPPAPAH & $2+$ \\
\hline & KM258880 & 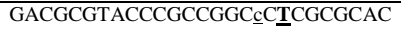 & DAYPPALAH & - \\
\hline & KM258881 & GACGCGTACCCGCCGGCCCCCGCGCAC & DAYPPAPAH & - \\
\hline : & KM258882 & 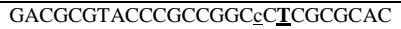 & DAYPPALAH & - \\
\hline$\overline{\bar{n}}$ & KM258883 & 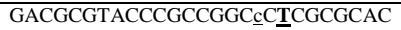 & DAYPPALAH & - \\
\hline & $\mathrm{B} / 1$ & GACGCGTACCCGCCGGC드드GCGCAC & DAYPPALAH & 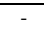 \\
\hline & $\mathrm{B} / 31$ & GACGCGTACCCGCCGGC드드CGCAC & DAYPPALAH & \\
\hline & $\mathrm{B} / 32$ & GACGCGTACCCGCCGGC드드CGCGCAC & DAYPPALAH & \\
\hline & $\mathrm{L} / 33$ & GACGCGTACCCGCCGGC드CCGCGCAC & DAYPPALAH & \\
\hline$\frac{a}{2}$ & $\mathrm{~L} / 5$ & GACGCGTACCCGCCGGCCCCCGCGCAC & DAYPPAPAH & $4+$ \\
\hline 랭 & $\mathrm{L} / 6$ & GACGCGTACCCGCCGGCCCCCGCGCAC & DAYPPAPAH & $4+$ \\
\hline & $\mathrm{L} / 9$ & GACGCGTACCCGCCGGCCCCCGCGCAC & DAYPPAPAH & $3+$ \\
\hline & $\mathrm{L} / 10$ & GACGCGTACCCGCCGGCCCCCGCGCAC & DAYPPAPAH & $3+$ \\
\hline & P-252 & GACGCGTACCCGCCGGCCCCCGCGCAC & DAYPPAPAH & $3+$ \\
\hline & P-375 & GACGCGTACCCGCCGGCCCCCGCGCAC & DAYPPAPAH & $3+$ \\
\hline
\end{tabular}

\section{RESULTS}

On the first day, the infected cells turn in to rounded and retractile cell, forming small gaps (Fig. 1). On second day, the gap is widening and the syncytium formation clearly appears (Fig. 2). The syncytium clearly visible in samples $\mathrm{L} / 5 ; \mathrm{L} / 6 ; \mathrm{L} / 9 ; \mathrm{L} / 10 ; \mathrm{P}-252$ and P-375 (which are assumed to be subtypes 1.1) but not performed a significantly differences from the samples $\mathrm{L} / 33 ; \mathrm{B} / 1 ; \mathrm{B} / 31$ and $\mathrm{B} / 32$ (which is assumed to be subtype 1.2) (Fig. 3 and Fig. 4).

In the following day, the number of syncytium increase, and filling the cavities. On the fourth day, it showed the presence of cell shape alteration of the infected cells (Fig. 5) The differences has been identified between samples L/5; L/6; L/9; L/10; P-252 and P-375 (which are assumed to be subtypes 1.1) and sample $\mathrm{L} / 33 ; \mathrm{B} / 1 ; \mathrm{B} / 31$ and $\mathrm{B} / 32$ (which is assumed to be subtype 1.2).
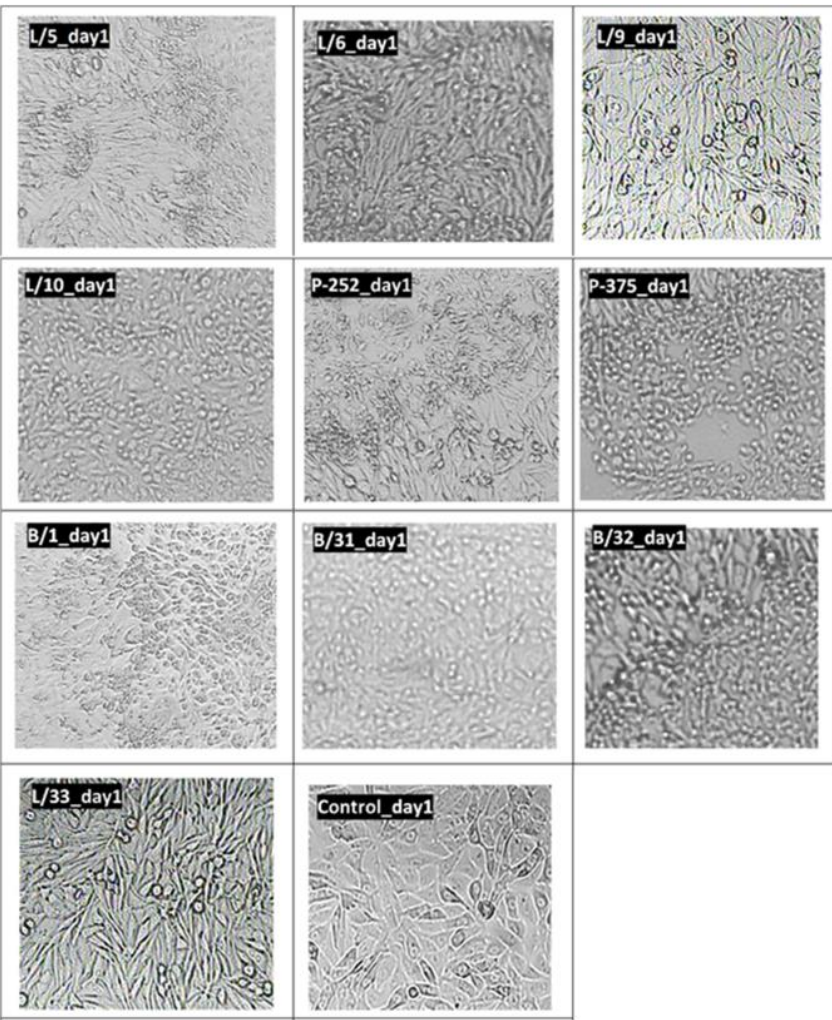

Fig. 1. The description of the inoculated BHK-21 cell on the first day 


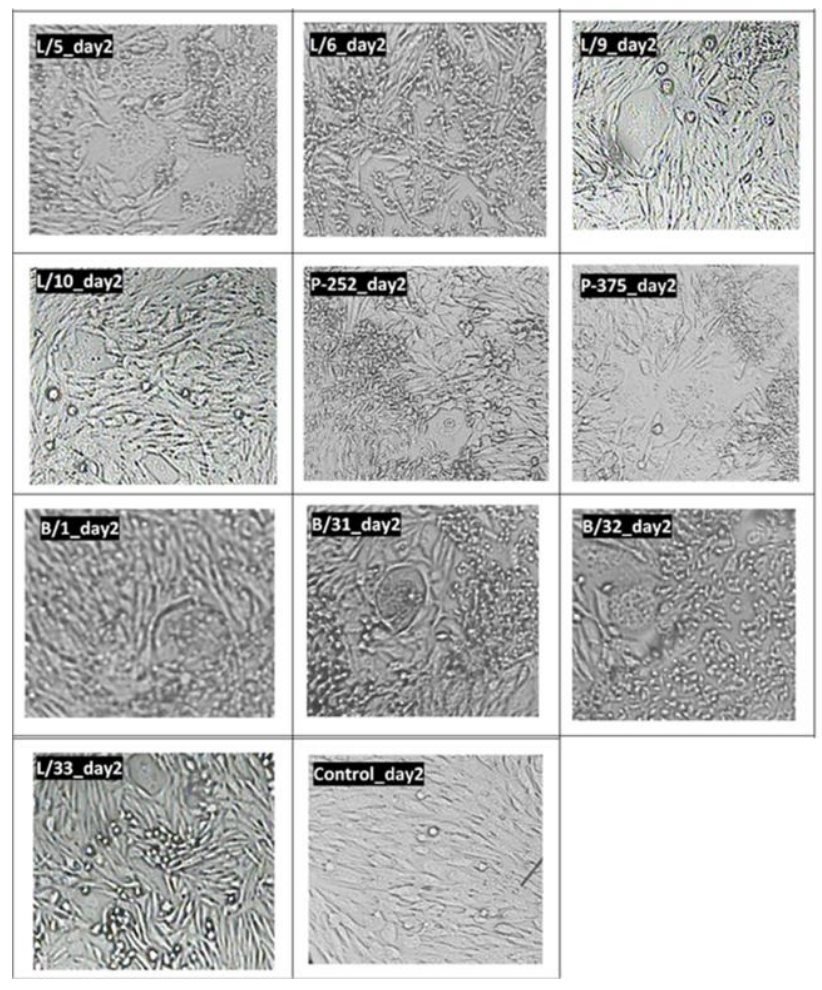

Fig. 2. The description of the inoculated BHK-21 cell on the second day

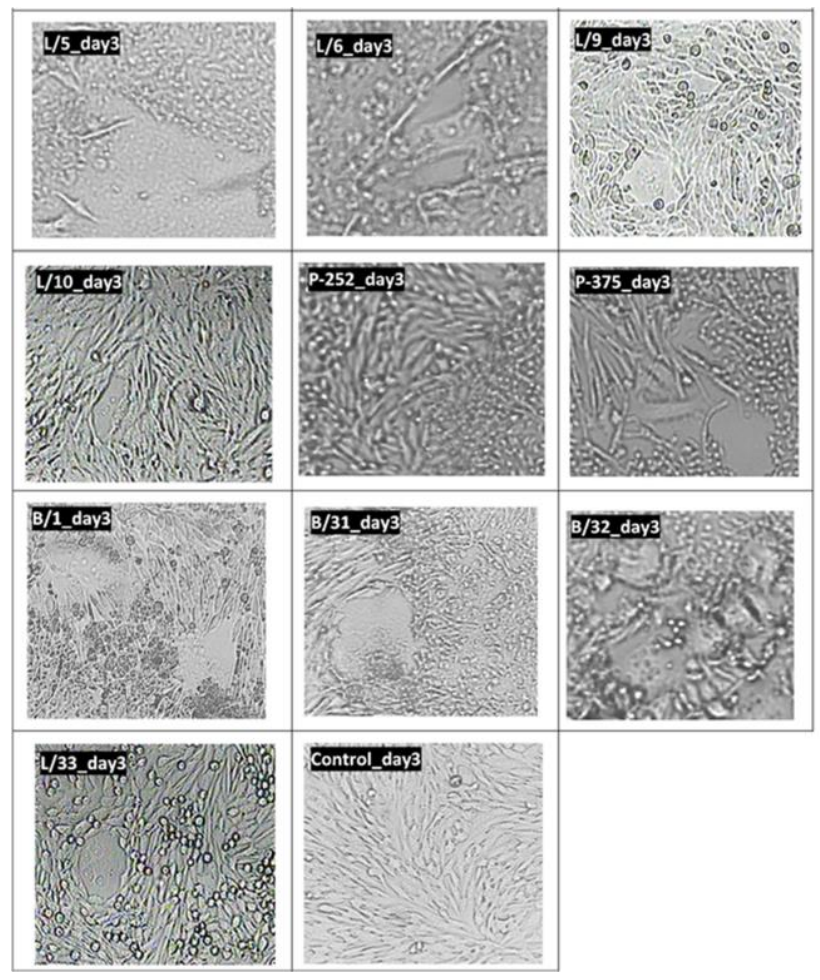

Fig. 3. The description of the inoculated BHK-21 cell on the third day
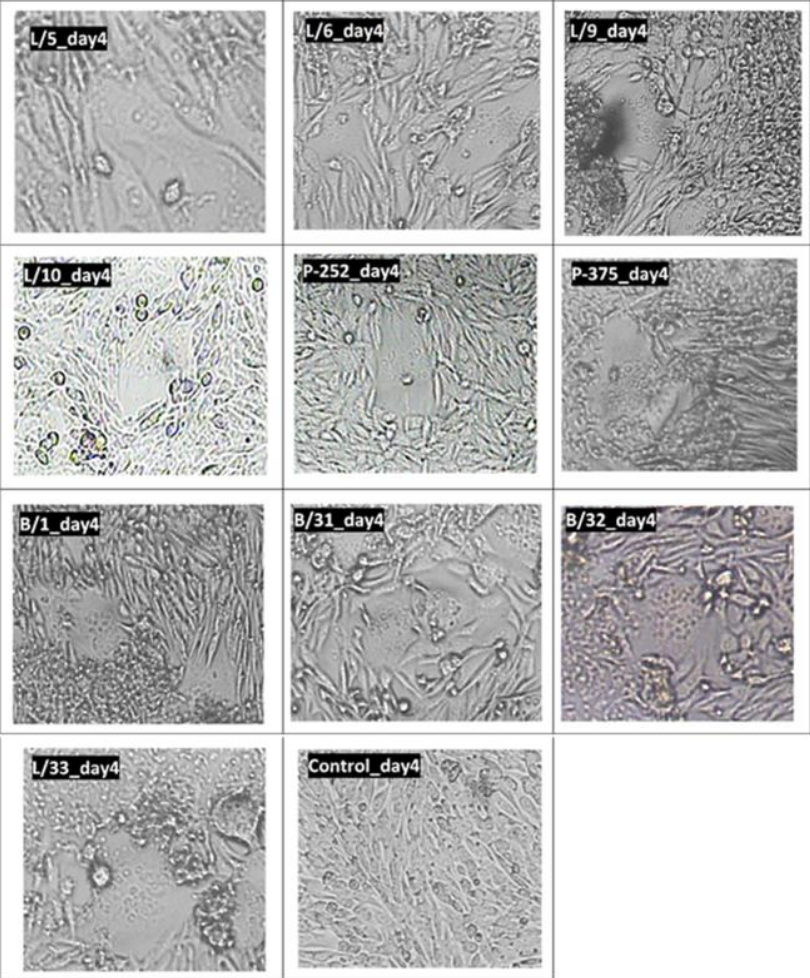

Fig. 4. The description of the inoculated BHK-21 cell on the fourth day

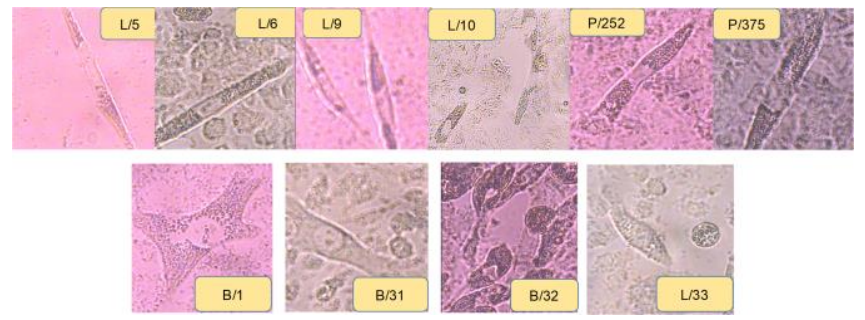

Fig. 5. The description of the persistently infected cell on the fourth day

\section{DISCUSSION}

The formation of the syncytium represents multiple cells that serve the same function and form a giant cell with many nuclei. The syncytium takes place because of the infection in the cell system. The myosin II that is followed by multinucleation that detain cytokinesis also plays a role in the formation of syncytium [15]. Some researchers examine the phenotypic description of the syncytium formation to find out the presence of gene mutation, especially the gD and UL36 [16] and [17]. Deletion of UL36 in HSV-1 causes accumulation of C-capsid in the cytoplasm [16]. In HSV, membrane fusion triggered by the $\mathrm{gD}$ gene induces a significant increase in membrane fusion [18].

It was reported that the BHV-1 also can bind Herpesvirus entry mediator $\mathrm{C}$ or well-known as nectin- 1 of Prr1 (HveC) receptor [19]. The experiment that uses BHKtk cells [20] and Chinese Hamster Ovary (CHO) cells transfected by the plasmid containing HveC, can make the cells susceptible to BHV-1 infection [21]. Other study reports that in the culture of the Syrian hamster cell, the 
BHV-1 infection depends on the titer magnitude of the inoculated virus. The virus infection can affect the alteration of the cell (multiplication >1), and the CPE can persistently observe (multiplication of about 0.5) [22]. The syncytium is one of a specific CPE alteration. Several viruses, including paramyxovirus [23], retroviruses [24], and herpesviruses produce the syncytium formation [18]. Several cells can be used to provide an appropriate picture of syncytia such as Baby Hamster Kidney (BHK) and Human Fetal Foreskin Fibroblast (HFFF2) [18]. Membrane fusion causes the formation of syncytium in enveloped viruses mediated by glycoproteins [25].

Based on this study observation, the infected cells experience vacuolization along the cytoplasmic area. In the cells L/5, L/6, L/9, L/10, P-252, and P-375 the shape of the cell were elongated, and the nucleus area is straight, while in $\mathrm{B} / 1, \mathrm{~B} / 31, \mathrm{~B} / 32$, and $\mathrm{L} / 33$, the form of the cell rounded, and the nuclear region is circular. According to [16], the UL36 gene that encodes the VP $1 / 2$ protein plays an essential role in helping the virus move to the nucleus with centripetal direction. However, this hypothesis should be proven by another specific study to investigate the relationship between this alteration to the characterization or mutation of the UL36 gene specifically. Furthermore, the appearance of these infected cells testifies about the condition of persistent infection in BHK-21 cell cultures inoculated by BHV-1. The previous study by [22] also supports this conclusion. [22] cultured the IBR virus in HEF and found a persistent infection of the cell. Furthermore, studies of IBR in BHK cells could give in-depth information about persistence and oncogenicity properties of BHV-1.

\section{ACKNOWLEDGMENT}

The author thank to the Director of Animal Health, Ministry of Agriculture of Indonesia; the head of PUSVETMA for providing the cell; the head of Animal Disease Investigation in Lampung and Bukittinggi for providing the animal samples.

\section{REFERENCES}

[1] OIE, "Infectious Bovine Rhinotracheitis / Infectious Pustular Vulvovaginitis". Office International des Epizooties (OIE). <http://www.oie.int.>

[2] Jones, C and Chowdhury, S. "Bovine Herpesvirus Type 1 (BHV-1) is an Important Cofactor in the Bovine Respiratory Disease Complex", 2010, Vet. Clin. North. Am. Food. Anim, vol. 26, pp 303 -321 .

[3] Jones, C and Chowdhury, S., 2007, "A Review of the Biology of Bovine Herpesvirus Type 1 (BHV-1), Its Role as a Cofactor in the Bovine Respiratory Disease Complex and Development of Improved Vaccines", Anim. Health Res. Rev. 8, 187 - 205.

[4] Metzler, A.E., Matile, H., Gassmann, U., Engels, M. and Wyler, R., 1985, "European Isolates of Bovine Herpesvirus 1: a Comparison of Restriction Endonuclease Sites, Polypeptides, and Reactivity with Monoclonal Antibodies", Arch. Virol., 85, 57 - 69.

[5] Wild P, Schraner EM, Peter J, Loepfe E, Engels M., 1998, "Novel Entry Pathway of Bovine Herpesvirus 1 and 5", J.Virol., 72, 9561 6.

[6] Kaashoek, M. J., and van Oirschot, J. T., 1996a, "Early Immunity Induced by A Live Ge-Negative Bovine Herpesvirus 1 Marker Vaccine", Vet. Microbiol. 53, 191 - 197.

[7] Miller J.M., Whetstone, C.A., der Maaten Van, M.J., 1991a. "Abortifacient property of bovine herpesvirus type 1 isolates that represent three subtypes determined by restriction endonuclease analysis of viral DNA", Am. J. Vet. Res., 52, 458-61.

[8] Adjid, R.M.A. dan Saepulloh, M., 2010, "Penyakit Infectious Bovine Rhinotracheitis pada Sapi di Indonesia dan Strategi Pengendaliannya", WARTAZOA., 20, 1.

[9] Kaashoek, M.J., Straver, P.J., Van Rooij, E.M.A., Quak, J. and Van Oirschot, J.T. 1996b, "Virulence, Immunogenicity and Reactivation of Seven Bovine Herpesvirus 1. 1 Strains: Clinical and Virological and Aspects", Vet. Record. 139, 416 - 421.

[10] Esteves, P.A., Dellagostin, O.A., Pinto, L.S., Silva, A.D., Spilki, F.R., Ciacci-Zanella, J.R., Hübner, S.O., Puentes, R., Maisonnave, J., Franco, A.C. and Rijsewijk, F.A.M., 2008, "Phylogenetic Comparison of the Carboxy-Terminal Region of Glycoprotein C (gC) of Bovine Herpesviruses (Bohv) 1.1, 1.2 and 5 from South America (SA)", Virus. Res. 131, 16 - 22

[11] d'Offay, J.M., Eberle, R., Fulton, R.W., and Kirkland, P.D., 2016 "Complete Genomic Sequence and Comparative Analysis of Four Genital and Respiratory Isolates of Bovine Herpesvirus Subtype 1.2 b (BoHV-1.2 b), Including the Prototype Virus Strain K22", Arch. Virol., 161, 3269 - 3274.

[12] Szpara, M.L., Parsons, L., Enquist, L.W., 2010., "Sequence Variability in Clinical and Laboratory Isolates of Herpes Simplex Virus 1 Reveals New Mutations" J. Virol., 84, 5303 - 13.

[13] Franti, M., Aubin, J.T., Poirel, L., Gautheret-Dejean, A., Candotti, D., Huraux, J.M., Agut, H., 1998, "Definition and Distribution Analysis of Glycoprotein B Gene Alleles of Human Herpesvirus 7”, J. Virol., 72, 8725 - 30.

[14] Noor, H.D., Tri, U., Haryadi, W.M., Widya, A., Koichi, A., 2019 , "DNA Sequence Variability Analysis of the gD and the UL36 Genes of Bovine Herpesvirus-1 Isolated from Field Cases in Indonesia", $J$. Appl. Anim. Res., 47, 206 - 11.

[15] Berk, A, Kaiser, C.A., Lodish, H., Amon, A., Ploegh, H., Bretscher, A., Krieger, M., Martin, K.C. 2008. Molecular cell biology. WH Freeman.

[16] Roberts, A.P., Abaitua, F., O'Hare, P., McNab, D., Rixon, F.J. and Pasdeloup, D., 2009, "Differing Roles of Inner Tegument Proteins pUL36 and pUL37 During Entry of Herpes Simplex Virus Type 1", J. Virol. 83, 105 - 116 .

[17] Owen, D., Crump, C. and Graham, S., 2015., "Tegument Assembly and Secondary Envelopment of Alphaherpesviruses", Viruses., 7, 5084 - 5114.

[18] Turner, A., Bruun, B., Minson, T., Browne, H., 1998 , "Glycoproteins gB, gD, and gHgL of Herpes Simplex Virus Type 1 Are Necessary and Sufficient to Mediate Membrane Fusion in a Cos Cell Transfection System", J. Virol. 72, 873 - 5.

[19] Connolly, S.A., Whitbeck, J.C., Rux, A.H., Krummenacher, C., Cohen, G.H., Eisenberg, R.J., 2001, "Glycoprotein D Homologs in Herpes Simplex Virus Type 1, Pseudorabies Virus, and Bovine Herpes Virus Type 1 Bind Directly to Human Hvec (Nectin-1) with Different Affinities", Virology., 280, 7-18.

[20] Cocchi, F., Menotti, L., Mirandola, P., Lopez, M. and CampadelliFiume, G., 1998, "The Ectodomain of a Novel Member of the Immunoglobulin Subfamily Related to the Poliovirus Receptor has the Attributes of a Bona Fide Receptor for Herpes Simplex Virus Types 1 and 2 in Human Cells", J. Virol., 72, 9992 - 10002.

[21] Geraghty, R.J., Krummenacher, C., Cohen, G.H., Eisenberg, R.J. and Spear, P.G., 1998, "Entry of Alphaherpesviruses Mediated by Poliovirus Receptor-Related Protein 1 and Poliovirus Receptor", Science. 280: 1618 - 1620.

[22] Michalski, F.J., Hsiung, G.D. 1976, "Persistent Infection with Bovine Herpesvirus-1 (Infectious Bovine Rhinotracheitis Virus) in Cultured Hamster Cells", In Vitro".,12, 682-6.

[23] Horvath, C.M., Paterson, R.G., Shaughnessy, M.A., Wood, R., Lamb, R.A., 1992, "Biological Activity of Paramyxovirus Fusion Proteins: Factors Influencing Formation of Syncytia", J. Virol., 66, 4564 - 9.

[24] Hildreth, J.E., Orentas, R.J., 1989, “Involvement of a Leukocyte Adhesion Receptor (LFA-1) in HIV-Induced Syncytium Formation", Science., 244, 1075 - 8.

[25] Stegmann, T., Doms, R.W., Helenius, A., 1989, "Protein-Mediated Membrane Fusion", Annu Rev Biophys Biophysic Chem., 18, 187 211 . 
[26] Zaichick, S.V., Bohannon, K.P., Hughes, A., Sollars, P.J., Pickard, G.E. and Smith, G.A., 2013, "The Herpesvirus VP1/2 Protein is an
Effector of Dynein-Mediated Capsid Transport and Neuroinvasion", Cell Host Microbe. 13, 193 - 203. 